Revista Eureka sobre Enseñanza y Divulgación de las Ciencias

ISSN: 1697-011X

revista.eureka@uca.es

Universidad de Cádiz

España

\title{
Fostering instructor-student argumentative interaction in online lecturing to large groups: a study amidst the Covid-19 pandemic
}

Archila, Pablo Antonio; Restrepo, Silvia; Truscott de Mejía, Anne-Marie; Rueda-Esteban, Roberto; Bloch, Natasha I.

Fostering instructor-student argumentative interaction in online lecturing to large groups: a study amidst the Covid-19 pandemic

Revista Eureka sobre Enseñanza y Divulgación de las Ciencias, vol. 19, núm. 1, 2022

Universidad de Cádiz, España

Disponible en: https://www.redalyc.org/articulo.oa?id=92068491008

DOI: https://doi.org/10.25267/Rev_Eureka_ensen_divulg_cienc.2022.v19.i1.1101 


\section{Fostering instructor-student argumentative interaction in online lecturing to large groups: a study amidst the Covid-19 pandemic}

Pablo Antonio Archila

Vice-Presidency of Research and Creation, Universidad de los Andes, Bogotá, Colombia

pa.archila@uniandes.edu.co

iD https://orcid.org/0000-0003-0225-4701

Silvia Restrepo

Vice-Presidency of Research and Creation, Universidad de

los Andes, Bogotá, Colombia

srestrep@uniandes.edu.co

(D) https://orcid.org/0000-0001-9016-1040

Anne-Marie Truscott de Mejía

School of Education, Universidad de los Andes, Bogotá,

Colombia

atruscot@uniandes.edu.co

(DD https://orcid.org/0000-0002-8380-8173

Roberto Rueda-Esteban

School of Medicine, Universidad de los Andes, Bogotá,

Colombia

rj.rueda32@uniandes.edu.co

(iD) https://orcid.org/0000-0002-5957-6261

Natasha I. Bloch

Department of Biomedical Engineering, Universidad de los

Andes, Bogotá, Colombia

n.blochm@uniandes.edu.co

(iD https://orcid.org/0000-0002-4769-1027
DOI: https://doi.org/10.25267/

Rev_Eureka_ensen_divulg_cienc.2022.v19.i1.1101

Redalyc: https://www.redalyc.org/articulo.oa?

$\mathrm{id}=92068491008$

Recepción: 19 Abril 2021

Revisado: 14 Julio 2021

Aprobación: 01 Septiembre 2021

\section{Abstract:}

The Covid-19 pandemic has accelerated the development and implementation of online education in higher education institutions around the globe. Online lecturing to large groups has been part of this acceleration. The problem is that synchronous face-toface lectures and synchronous online lectures are widely criticized for reinforcing the hegemony of instructor-centered traditional approaches and rarely involving instructor-student and student-student argumentative interaction. This study aimed to provide evidence that online informal formative assessment (OIFA) can be used to provide undergraduates with explicit opportunities to participate in instructor-student argumentative interaction. An OIFA-based pedagogical strategy was implemented amidst the Covid-19 pandemic in the online lecturing sessions of a science course with 76 undergraduates ( 40 females and 36 males, 16-23 years old) in Colombia. It was found that OIFA can contribute to instructor-student argumentative interaction as well as to being able to better address undergraduate learning needs. Practical implications for university science education in the pandemic and post-pandemic eras are discussed. 
KEYWORDS: Covid-19, formative assessment, instructor-student argumentative interaction, online learning, university science education

\section{INTRODUCTION}

On December 31, 2019, a cluster of severe pneumonia cases of unknown aetiology in the city of Wuhan, Hubei Province, in central China, was reported by the Chinese Center for Disease Control. On January 30, 2020, The World Health Organization (WHO) "declared the outbreak to be a public health emergency of international concern" (WHO 2020a, p. 1). Six weeks later (March 11, 2020), WHO declared coronavirus disease 2019 (Covid-19) to be a pandemic (WHO 2020b). Recently, Erduran (2021) noted that "the pandemic context is helping researchers galvanize new and fresh perspectives on how to understand and improve science education to make it relevant for today's circumstances" (p. 201). With this in mind, it is now something of a truism to say that the Covid-19 pandemic has accelerated the development and implementation of online courses in higher education institutions around the globe. It is very likely this situation will continue in the post-pandemic era. This transformation in education has presented a common challenge to multiple universities that focused much of their efforts on strengthening their learning management systems (e.g., Blackboard Learn ${ }^{\mathrm{rx}}$, Canvas, Moodle), and much less effort considering how to guide instructors in the creation, implementation, and assessment of authentic and meaningful online educational practices. One consequence of this is that the traditional (and outmoded) synchronous face-toface lecture format has evolved into synchronous online lecture (Mahmood 2021; Sun et al. 2020).

In the case of face-to-face lectures, Hoidn and Klemenčič (2021) criticize them for reinforcing the hegemony of instructor-centered traditional approaches. Given this situation, it is probably not so surprising that research has found that this type of practice rarely involves instructor-student and student-student argumentative interaction (e.g., Archila et al. 2018, 2019, 2020). In many lectures, the instructor assumes an authoritative (dominant) stance, doing most of the talking (and/or reading PowerPoint slides) while students merely remain passive and silent. "There can be nothing more demotivating for students than sitting in a lecture where the lecturer is monotone, the PowerPoint presentation is a predictable list of bullet points and at no point do they feel part of the lecture" (Morton 2009, p. 64). Clearly, it is hard to imagine that undergraduates would be able to develop a desirable process of knowledge construction under these conditions. Therefore, Matsushita (2018) and Mayer (2004) assert that lecture-based knowledge transmission is a good example of what a non-constructivist practice is.

Mahmood (2021) and Sun et al. (2020) maintain that the Covid-19 pandemic is a valuable opportunity for instructors to patiently abandon the espoused and enacted belief that students are passive listeners (absorbers of information) and/or note takers and start to include interaction and open discussion more frequently in their online lectures. In relation to this, Hoidn and Klemenčič (2021) recommend combining lectures with active learning practices as a way to facilitate more meaningful or deeper learning. In the case of university science education, the combination lecture-active learning seems to be a rational and reasonable possibility whether we acknowledge that many science courses rely primarily on lecture (Wieman 2017). Archila (2017) and Archila et al. (2020, 2021a, 2021b) maintain that engaging students in argumentative interaction is a powerful form of active learning, pointing out that argumentative interaction is not a common practice in university education.

Our study is inspired by the reflection that the impact of this pandemic on contemporary science and society is likely to be felt for a long time (Erduran 2020a). In the context of the Covid-19 crisis, we explored the use of online informal formative assessment (OIFA) - a fairly specific type of assessment for learning in which feedback is instantaneous (Rached and Grangeat 2021) - as educational ally for online lecturing to large groups. Specifically, this study aimed to provide evidence that OIFA can be used to give undergraduates explicit opportunities to participate in instructor-student argumentative interaction. To this end, we created 
and implemented an OIFA-based pedagogical strategy. The present study posed the following two research questions:

RQ1: To what extent does the OIFA-based pedagogical strategy provide students with explicit opportunities to participate in instructor-student argumentative interaction during online lecturing?

RQ2: What is the opinion of the students about the use of OIFA in online lecturing?

\section{THEORETICAL FRAMEWORK}

We define learning as constructing meaning and reflecting critically on this meaning. Accordingly, (1) online leaning, (2) active learning, (3) argumentative interaction, and (4) informal formative assessment, are four essential elements of our OIFA-based pedagogical strategy. In this section, the theoretical foundations of these four notions are discussed. To start with, it is important to clarify that the term "online learning" is an umbrella term. It is widely used but has multiple meanings. In this article, online learning is defined as the use of digital technologies (e.g., computers, smartphones, tablets) with Internet access to provide a learning experience that may take place synchronously or asynchronously (Zhu and Liu 2020). This definition largely explains why online learning was rapidly adopted to face the challenge of the Covid-19 pandemic. Sunal and Wright (2012) underscore the following characteristics of a desirable online learning environment: pedagogical practice based on constructivism, concrete actions to foster authentic learning, student-centered learning, learning engagement through a variety of pedagogic strategies, and active learning.

The idea that desirable online (and offline) learning requires active learning practices is a recurring reflection (Salmon 2013). In the context of university education, Mizokami (2018) defines active learning as "all kinds of learning beyond the mere one-way transmission of knowledge in lecture-style classes (= passive learning). It requires engagement in activities (writing, discussion, and presentation) and externalizing cognitive processes in the activities" (p. 79). In active learning environments, students assume the role of debaters, critical thinkers, decision makers, and self-directed learners, while the instructor acts as a creative facilitator for learning. Her/his function is not only to provide students with explicit opportunities to collaborate, construct, experiment, interact, and reflect, but also to think about what and why they are doing this (Gogus 2012).

According to Matsushita (2018), three aspects can be considered for deep active learning, namely: (1) deep learning; (2) deep understanding; and (3) deep engagement. In relation to the first, deep learning occurs when the student constructs meaning by herself/himself, while in surface leaning the student focuses solely on coping with course requirements (e.g., passing an exam). With respect to the second, deep understanding is achieved when the student not only internalizes knowledge, but also reconstructs this through externalization activities (e.g., debate, role playing, writing). Concerning the third aspect, deep engagement (involvement) refers to the articulation of motivation and active learning. Matsushita (2018) also stresses that acquisition and understanding of knowledge (internalization) is an important prerequisite in the promotion of higher-order thinking skills (e.g., argumentation, critical thinking) and externalization of cognitive processes. She contends that this is a good reason why deep active learning can contribute to the transformation of education based on one-sided lectures by the instructor into a more meaningful and reflective learning experience that articulates lecture classes and active learning classes.

Bonwell and Eison (1991) are widely recognized for their criticisms of the instructor-centered lecture format and their efforts to foster active learning in higher education. In this regard, Morton (2009) commented that "much of the writing in the late 1980s indicated that sitting in lectures was not always a particularly effective way for students to learn and predicted that the next few years would see the demise of the lecture" (p. 58). The key problem, however, is that lecturing is still a popular practice is science courses. Given this situation, Wieman (2017) highlights the need for implementing active learning strategies in these 
courses. He recommends student-instructor and student-student interaction as one concrete active learning action, among many, to improve educational practices.

"Argumentation studies have been a successful line of research in science education since its first steps at the end of the 1990s" (Jiménez-Aleixandre and Brocos 2017, p. 117). In line with this, Erduran et al. (2020), Jiménez-Aleixandre and Brocos (2021), and Namdar and Namdar (2021) contend that, nowadays, argumentation is widely accepted as a key higher-order skill that should be explicitly promoted. Here, we define argumentation "as the connection between claims and data through justifications or the evaluation of knowledge claims in light of evidence, either empirical or theoretical" (Erduran and JiménezAleixandre 2007, p. 13). Likewise, Jiménez-Aleixandre and Brocos (2017) maintain that argumentative interaction is a branch of argumentation. In the present article, argumentative interaction is defined as a form of communication in which two or more people exchange and/or co-construct arguments in a dialogic-egalitarian (symmetric) dialogue-atmosphere. There are at least three reasons that explain why argumentative interaction is considered as a type of active learning. First, constructing an argument in a rational and reasonable way requires a high-level of understanding of content knowledge (internalization) and a high-level of cognitive processing (externalization-argumentative skills) (Archila 2015; Archila et al. 2018). Second, Jiménez-Aleixandre (2007) and Muller Mirza (2015) have observed that argumentative interaction is a concrete opportunity for the active participation of the students in meaning-making processes. And third, Archila (2015, 2018), Baker (2009), and Jiménez-Aleixandre and Puig (2012), maintain that exchanging and/or co-constructing arguments implies the evaluation of arguments-a skill required to reflect critically on the meaning that is being constructed.

The three main ideas presented in the above paragraphs can be summarized as: (1) online learning has been adopted worldwide to face the Covid-19 pandemic (Zhu and Liu 2020); (2) active learning is a key aspect of a desirable online learning environment (Salmon 2013), and (3) argumentative interaction is a form of active learning (Archila et al. 2018, 2020, 2021a; Baker 2009; Jiménez-Aleixandre 2007; Muller Mirza 2015). Nonetheless, Archila et al. (2020) note that university courses rarely involve undergraduates in argumentative interaction. The use of OIFA in online lecturing to provide students with explicit opportunities to participate in instructor-student argumentative interaction is an underresearched possibility in science education. Cowie (2012) states that an assessment is formative when the assessment information (e.g., exam responses, students' presentations, written productions) are used to improve teaching and learning. She also highlights the key role of instructor-student and studentstudent interaction in formative assessment practice. There is broad agreement among researchers that useful feedback is at the heart of formative assessment (e.g., Cowie 2012; Duss 2020; Rached and Grangeat 2021). Feedback can be preplanned-formal formative assessment-(Holmeier et al.2018; Yin et al. 2014) and/ or take place during the course of events-informal formative assessment-(Archila et al. 2018; Rached and Grangeat 2021). Whatever the type of formative assessment (formal or informal), scholars argue that fostering genuine and meaningful formative assessment practices in university education is an issue that deserves more attention (e.g., Cosi et al.2020; Duss 2020).

\section{The OIFA-BASED PEDAgOgicAl STRATEgy}

In this section, we explain how online leaning, active learning, argumentative interaction, and informal formative assessment were integrated within our OIFA-based pedagogical strategy (Fig. 1). 


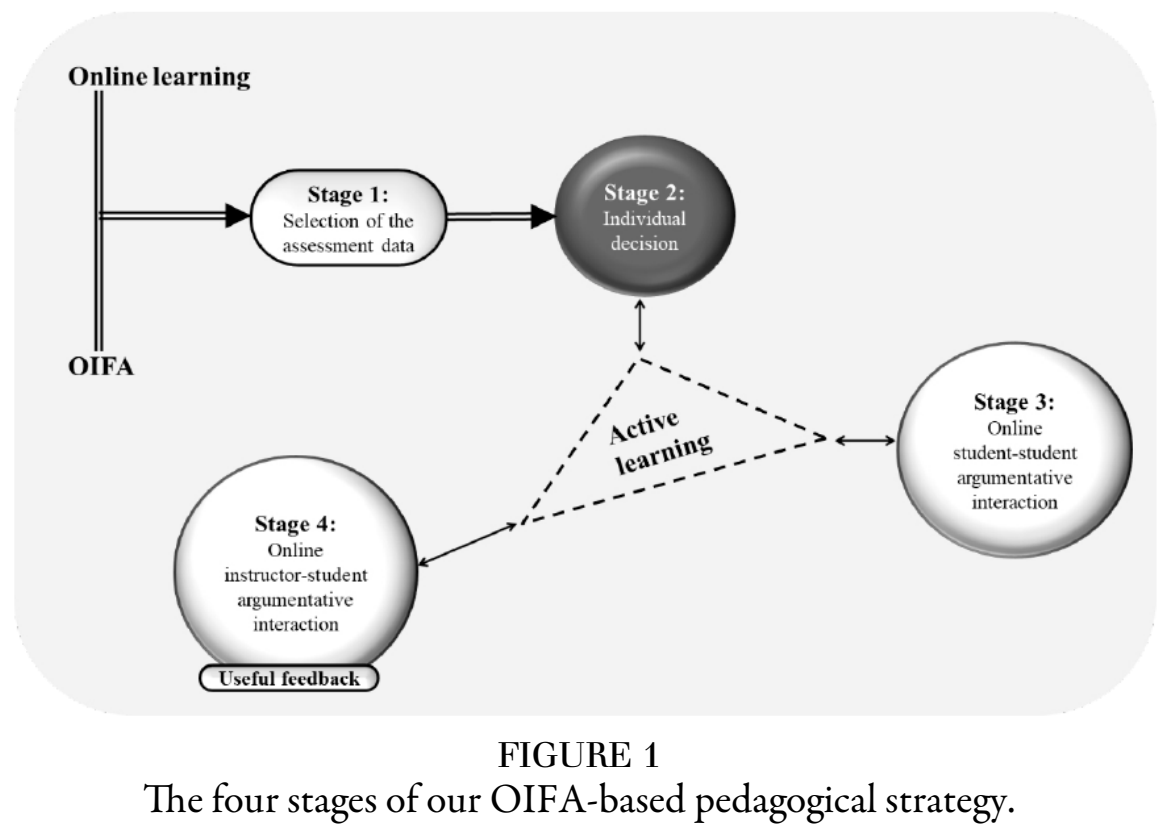

This strategy consists of four stages. Each of these stages is equally relevant as the next because each has a specific objective to provide students with opportunities to engage in online argumentative interaction. The first stage deals with the selection of the assessment data (Cowie 2012). In this stage, the instructor carefully selects the assessment data (e.g., exam responses, students' presentations, written productions) that s/he considers more relevant to discuss in depth with the students. The second stage involves making an individual decision. In this stage and as an active part of the lecture, each student is asked to make an individual decision (e.g., In your opinion, which answer in more rational and reasonable?) about the assessment data previously selected by the instructor in Stage 1. The third stage of the OIFA-based pedagogical strategy focuses on online student-student argumentative interaction. In this stage, the students discuss in small groups online the decisions each made in Stage 2 individually and try to reach a consensus. This stage is an explicit and valuable opportunity for students to evaluate, exchange and/or co-construct arguments. The fourth and last stage is dedicated to online instructor-student argumentative interaction. Specifically, in a whole-class discussion, the instructor listens online to those students who voluntarily communicate their agreed decision and uses their opinions as a springboard to interact argumentatively online with them and provide useful feedback to the whole class.

\section{METHOD}

\section{Context and participants}

The OIFA-based pedagogical strategy (Fig. 1) was implemented in a university science course called: Quantitative Physiology I. We chose this course because of convenient access (Bryman 2016) as well as the course characteristics. This is a large (90-110 students per semester) undergraduate course that is offered every semester by the Department of Biomedical Engineering, at a prestigious private university in Bogotá, Colombia. The Quantitative Physiology I course is delivered over a 16-week period and is comprised of two lectures per week (75 min each) and a weekly 120 min laboratory practice. Due to the Covid-19 crisis, the course became completely virtual, with online lectures, as well as completely redesigned laboratory practices. Students have access to the course information, tools (e.g. audio and video recordings of the lectures), and assignments through Blackboard Learn ${ }^{\text {rx }}$, while Blackboard Collaborate ${ }^{\mathrm{rx}}$ and Zoom are used 
for lectures. Two instructors (Instructor 1 and Instructor 2) alternate in giving the lectures. Instructor 1 is an expert in Biology and Quantitative Physiology, while Instructor 2 is an expert in Anatomy and Medical Physiology. They participated in the construction of the pedagogical strategy and were wholly committed to implementing it while virtual education remains necessary. They introduced several changes in the online lecture sessions for better implementation. To be precise, they allocated less time for content presentation and more time for students to make an individual decision (Stage 2 in Fig. 1), as well as online student-student argumentative interaction (Stage 3 in Fig. 1), and online instructor-student argumentative interaction (Stage 4 in Fig. 1).

In Colombia, it is expected that students will begin the five grades of their primary school education when they are 6 years old. Afterwards, they continue with the four grades of middle-school education at the age of 11 . Following this, students begin the two grades of their high school education when they are 15 years old. Thus, in theory, it is expected that people begin their university education at the age of 17 (Ministerio de Educación Nacional 2008). In practice, Archila $(2017,2018)$ and Archila et al. (2021c) have found students who were 16 years old enrolled in university courses. The reason for this is that these students were only a few months away from their 17 th birthday. With this in mind, the participants of this study were 76 students ( 40 female and 36 male), aged 16 to 23 years-old $(M=18.1 ; S D=1.19)$, enrolled in the Quantitative Physiology I course. This research was approved by the University's Ethics Committee. At the beginning of the course, the aims of the investigation were explained to the participants and the kind of online interactions they were expected to take part in. According to the ethical guidelines of the American Psychological Association, informed consent was sought from the undergraduates and their parents (for minors below 18 years old, the age of consent). Also, the participating students were told that their results would only be used for the purposes of the investigation and that they would in no way influence their grades in the course. Most importantly, participants were informed about the possibility they could stop taking part in the research whenever they wanted. Participation was voluntary and it was made clear to students that this was completely anonymous.

\section{The OIFA-based pedagogical strategy in the Quantitative Physiology I course}

The OIFA-based pedagogical strategy was implemented in the online lecture sessions of the Quantitative Physiology I course. Every two weeks, participants answered a 10-item quiz (in total seven quizzes) about the topics presented during this period (e.g., cell transport mechanisms, muscle anatomy, sensory physiology). They were given 30-min to answer each quiz. It is important to clarify that all the items were taken from a confidential item (question) bank that is owned and held in copyright by a third party. For this reason, regretfully, we are not allowed to give examples of these in this article. Participants' answers to these items were fundamental as they represented the assessment information (Cowie 2012). To be precise, it was from this information that in Stage 1 (Fig. 1), the instructor selected two (in total 14 questions) of the ten items (in total 70 questions), prioritizing those in which students had more trouble.

The day next after the students had answered the 10-item quiz, at the beginning of the online lecture, they were presented with a slide which displayed one of the two questions previously selected by the instructor. As planned in the second stage of the strategy, participants were asked to make a decision about this question individually (\#5-min). The purpose of this stage is to give student a second opportunity to reflect on the decision s/he made and organize her/his ideas before the small-group discussion. Then, students were engaged in online student-student argumentative interaction through discussion in small groups, in which each group was asked to make a joint decision (7-12-min) (Stage 3 in Fig. 1). In the fourth stage, an online whole class discussion was the scenario for online instructor-student argumentative interaction and useful feedback (15-20-min). After this, Stages 2 (individual decision), 3 (online student-student argumentative 
interaction), and 4 (online instructor-student argumentative interaction) were repeated with the second question previously selected by the instructor.

\section{Data collection}

Data were collected from Stage 4 of the OIFA-based pedagogical strategy (Fig. 1) for one reason: this stage is the main scenario of instructor-student argumentative interaction which is the focus of our study. More specifically, the online instructor-student argumentative interactions that took place during Weeks 2, 4, 6, 8 , 10,12 , and 14 were audio recorded. Additionally, in the last session of the implementation of the pedagogical strategy, and as a way of finding out about the opinion of the participating students about the use of OIFA in online lecturing, and thus receive feedback for future improvements of our strategy, they were asked to answer a 11-item online anonymous survey (Appendix). This instrument was based on previous intervention surveys used by Archila et al. (2020, 2021a, 2021b) to find out about the level of contribution of interventions focused on the promotion of argumentative interaction (items 1, 5, and 6) and receive undergraduates' feedback (items 2, 3, 4, 7, 8, 9, 10, and 11).

\section{Data analysis}

To answer our RQ1, "To what extent does the OIFA-based pedagogical strategy provide students with explicit opportunities to participate in instructor-student argumentative interaction during online lecturing?”, we used the qualitative data analysis software Transana" (Rush 2019) to transcribe and code audio-recordings of the episodes in which the instructor-student argumentative interaction took place. Table 1 shows the five codes used. The coding was conducted independently by three coders. The Fleiss's kappa (Fleiss 1971) was calculated to assess the inter-coder reliability of this coding which was based on a single yesno coding method. This method was used since the inter-coder reliability involved more than two coders. Fleiss's kappa calculated was $0.687\left(S_{\mathrm{K}}=0.098 ; \mathrm{Z}=7.023 ; p<10-3\right)$ for Week $2 ; 0.712\left(\mathrm{~S}_{\mathrm{K}}=0.151 ; \mathrm{Z}\right.$ $=4.714 ; p<10-3)$ for Week 4; $1.000\left(S_{K}=0.153 ; Z=6.529 ; p<10-3\right)$ for Week 6; $0.860\left(S_{K}=0.108\right.$; $Z=7.978 ; p<10-3)$ for Week 8; $0.845\left(S_{K}=0.132 ; Z=6.399 ; p<10-3\right)$ for Week 10; $0.850\left(S_{K}=\right.$ $0.108 ; Z=7.835 ; p<10-3)$ for Week 12; and $0.658\left(S_{K}=0.077 ; Z=8.577 ; p<10-3\right)$ for Week 14 . These values are greater than 0.61; this is considered a "substantial agreement" (Viera and Garrett 2005, p. 362). A consensus was reached after some discussion and further examination of the corpus. This coding was used to calculate the percentage of the aspects of argumentation (Table 1) that were discussed by the class (not by each student) in the seven feedback sessions.

Finally, to answer RQ2, "What is the opinion of the students about the use of OIFA in online lecturing?", the students' responses to the 11-item online anonymous survey were analyzed using frequency counts (Questions 1, 4, 5, and 6 in Appendix). Some answers to open-ended questions (Questions 2 and 3 in Appendix) are commented on in the Results section. In addition, responses to Questions 7 to 11 (Appendix), were placed on a rating scale range of frequency from Strongly Disagree (1) to Strongly Agree (5). The Statistical Package for the Social Sciences (SPSS) was used to conduct exploratory factor analysis. The Kaiser-Meyer-Olkin value obtained was 0.88 . Bartlett's test of sphericity gave a value of 274.571 with $p<$ 0.000 . We decided to include all the five items in our analysis as they showed factor loadings between 0.77 and 0.90 (Mindrila 2017). It is important to point out that these results need to be treated with great caution since Bryman (2016) insists that factor analysis should be conducted if the study includes "large numbers of variables" (p. 691), which is not our case. Finally, the Cronbach's alpha coefficient of these items was calculated. The coefficient obtained was 0.92 which corresponds to an "excellent" (George and Mallery 2020, p. 244) internal consistency. 
TABLE 1

Codes used in the coding data of the instructor-student argumentative interaction.

\begin{tabular}{|c|c|c|}
\hline Code & Description & Example \\
\hline 1 & $\begin{array}{l}\text { Students communicate a claim-assertion } \\
\text { or proposition offered by the student } \\
\text { (Archila et al. 2018) }\end{array}$ & $\begin{array}{l}\text { "Paracrine substance is the type of chemical } \\
\text { messenger that one would expect to find for a } \\
\text { local and intercellular response" (U70, Question } 2 \\
\text { in Feedback session 1) }\end{array}$ \\
\hline 2 & $\begin{array}{l}\text { Students communicate arguments_-reason } \\
\text { and/or evidence put forward by the } \\
\text { student to support a claim (Archila et al. } \\
\text { 2018) }\end{array}$ & $\begin{array}{l}\text { "The brachialis muscle is the one that performs the } \\
\text { movement for the flexion of the elbow. The } \\
\text { biceps brachii support this movement where the } \\
\text { brachialis would be the main muscle and the } \\
\text { biceps [brachii] would be the synergist. As we are } \\
\text { talking about flexion and not extension, in this } \\
\text { case the triceps would be acting as an antagonist } \\
\text { muscle" (U50, Question } 2 \text { in Feedback session 4) }\end{array}$ \\
\hline 3 & $\begin{array}{l}\text { Students communicate a counterclaim- } \\
\text { assertion or proposition offered by the } \\
\text { student that refutes a claim (Muller Mirza } \\
\text { 2015) }\end{array}$ & $\begin{array}{l}\text { "I disagree. In my view, it is common to find this } \\
\text { type of hormones [peptide and/or catecholamine] } \\
\text { attached to other proteins" (U35, Question } 2 \text { in } \\
\text { Feedback session 7) }\end{array}$ \\
\hline 4 & $\begin{array}{l}\text { Students communicate counterarguments- } \\
\text { reason and/or evidence put forward by } \\
\text { the student to support a counterclaim } \\
\text { (Muller Mirza 2015) }\end{array}$ & $\begin{array}{l}\text { "It seems to me that the brachialis is the synergist } \\
\text { because it is the muscle that helps to stabilize and } \\
\text { direct movement when the elbow is flexed. Also, I } \\
\text { consider that the biceps [brachii] is the agonist } \\
\text { because it is the one that performs the } \\
\text { contraction" (U32, Question } 2 \text { in Feedback } \\
\text { session 4) }\end{array}$ \\
\hline 5 & $\begin{array}{l}\text { Students explicitly reflect on their } \\
\text { argumentation processes-the student is } \\
\text { aware of the process s/he followed to } \\
\text { make a decision (Baker 2009) }\end{array}$ & $\begin{array}{l}\text { "To make a decision, we [referring to s/he and } \\
\text { her/his small groupmates] started by considering } \\
\text { that the answers do not determine the magnitude } \\
\text { of the action potentials, that is, the power of the } \\
\text { receptor potential never determines the magnitude } \\
\text { of the action potential. That said, options "A" and } \\
\text { "C" are not acceptable. Then, we had in mind the } \\
\text { fact that afferent neurons do not generate action } \\
\text { conditions with specialized receptors, they do not } \\
\text { generate action potentials. This is the reason why } \\
\text { "E" is not acceptable. Options "B" and "D" are } \\
\text { acceptable options" (U22, Question } 1 \text { in Feedback } \\
\text { session 4). }\end{array}$ \\
\hline
\end{tabular}

\section{Results}

\section{Instructor-student argumentative interaction}

Instructor-student argumentative interaction is a good opportunity for students to discuss various aspects of argumentation, such as (counter) claim, (counter) arguments, and explicit reflection on the argumentation process. Figure 2 shows the percentage of the aspects that were referred to by the class in the seven feedback sessions (FS). "Claim" and "arguments" are the only two elements that were used by the students in all the seven sessions. This indicates that undergraduates did not have much trouble in putting forward a claim and developing arguments when interacting with their instructor in the feedback sessions. Clearly, this is a step in the right direction, towards the promotion of argumentation in science education. An important reason for this is that (1) claim and (2) arguments are widely recognized as two pillars of any argumentation process (Erduran and Jiménez-Aleixandre 2007). A second step has to do with the presentation of counterclaims and 
counterarguments. Our results suggest that this is the step which should be more emphasized, since students presented both counterclaim and counterarguments in only five out of the fourteen questions. As Namdar and Namdar (2021) observe, this is a great challenge for the students since it requires them to go further than an initial (and often apparently rational and reasonable) argumentation and explore other possibilities that result in the anticipation of counterclaims and counterarguments. Likewise, "go further" is a key opportunity for students to move beyond their comfort zone: the mere production of claims and arguments.

Figure 2 also indicates that the percentage of the aspects that were discussed by the class varied across the seven feedback sessions. This situation cannot be judged as a "good" or "bad" result. Here the crucial point is that students made use of (counter) claim, (counter) arguments, and explicit reflection on the argumentation process during instructor-student argumentative interaction. This occurred particularly in FS1:W2:Q1, FS4:W8:Q1, FS4:W8:Q2, FS7:W14:Q1, and FS7:W14:Q2. In this sense, a bad results is the fact that in Feedback session 5:Week 10:Question 1 (FS5:W10:Q1), 50\% of the instructor-student argumentative interaction focused on students' claims while the other $50 \%$ was used to present students' arguments. This is a bad result because the discussion of counterclaims and counterarguments did not take place. In fact, explicit reflection did not occur at all. Fortunately, we found that this was not a recurrent situation in our study. To be precise, Figure 2 shows that "explicit reflection on the argumentation process" occurred in twelve out of the fourteen questions. It is therefore valuable to find that this demonstrates that it is possible to move towards the transformation of instructor-centered traditional online lecturing into student-centered scenarios, even in times of Covid-19. It is worth mentioning that instructor-student argumentative interaction served as scenario to make this reflection explicit. In other words, having to interact argumentatively with their instructor forced participants to explicitly reflect on their argumentation process. This is a potential contribution of the study if we acknowledge that "nowadays, argument and debate are virtually absent from university science education" (Archila et al. 2020, p. 647). Therefore, and as a response to our first research question, Figure 2 indicates that even though the OIFA-based pedagogical strategy effectively provided undergraduates with explicit opportunities to participate in instructor-student argumentative interaction during synchronous online lecturing, there is much work to be done to help students to produce counterclaims and counterarguments.

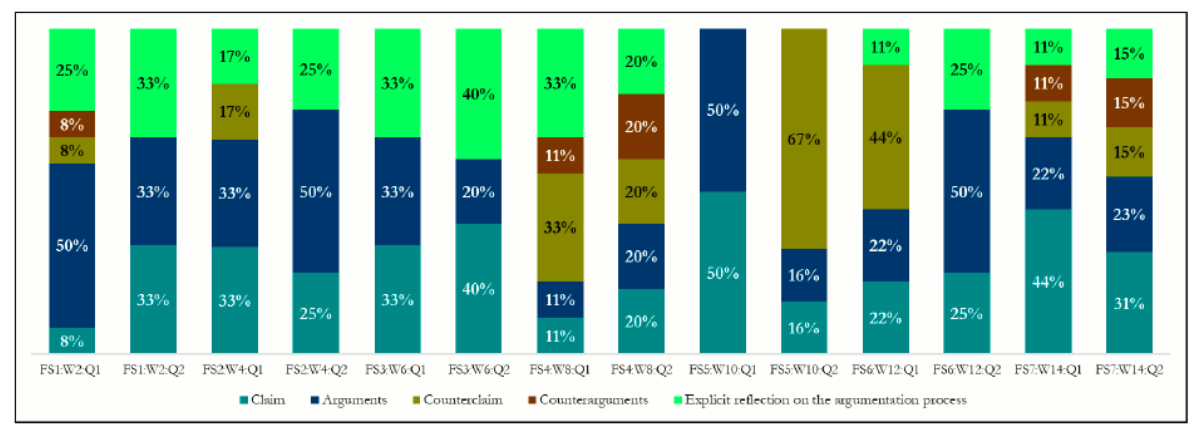

FIGURE 2

Results of students' argumentation during instructorstudent argumentative interaction $F S$ feedback session $W$ week $Q$ question Note Totals may not add to $100 \%$ because of rounding

\section{Undergraduates' opinion about the use of OIFA}

Figures 3 and 4 display the students' responses to Questions 1 to 6 of the 11 -item survey. While it is encouraging to know that $78 \%$ of the students who answered the survey had received instruction in argumentation before taking the Quantitative Physiology I course (Q1 in Fig. 3), it should be mentioned that more than half of the respondents $(56 \%)$ never $(18 \%)$ or infrequently $(38 \%)$ had the opportunity to 
participate in online feedback sessions that involve small-group discussions in other university online courses in times of Covid-19 (Q6 in Fig. 4). Likewise, we found that almost half of the students (44\%) never (8\%) or infrequently (36\%) had the opportunity to participate in online feedback sessions in other university online courses (Q5 in Fig. 4). These outcomes give us an idea of the importance of our OIFA as it provided students with opportunities that they usually did not find in other courses.

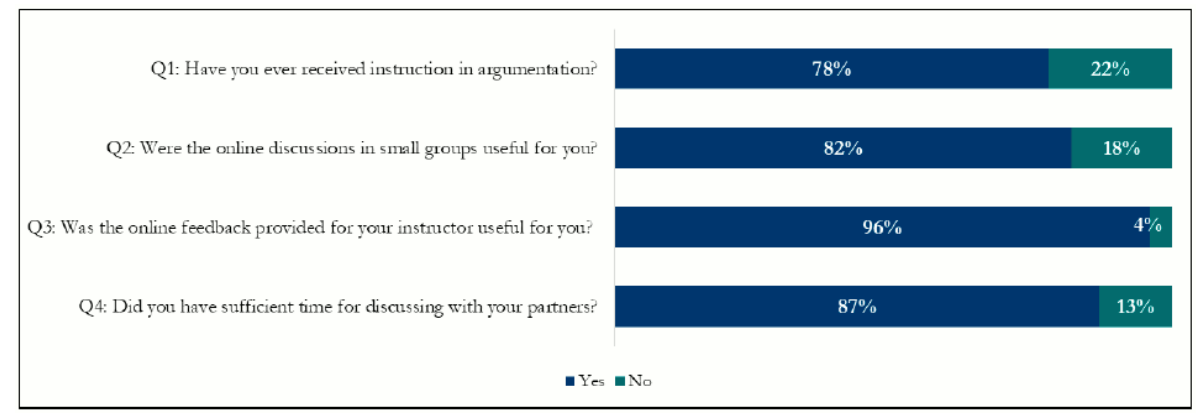

FIGURE 3

Students' responses to Questions 1 to 4 of the 11 -item survey $(\mathrm{N}=76)$

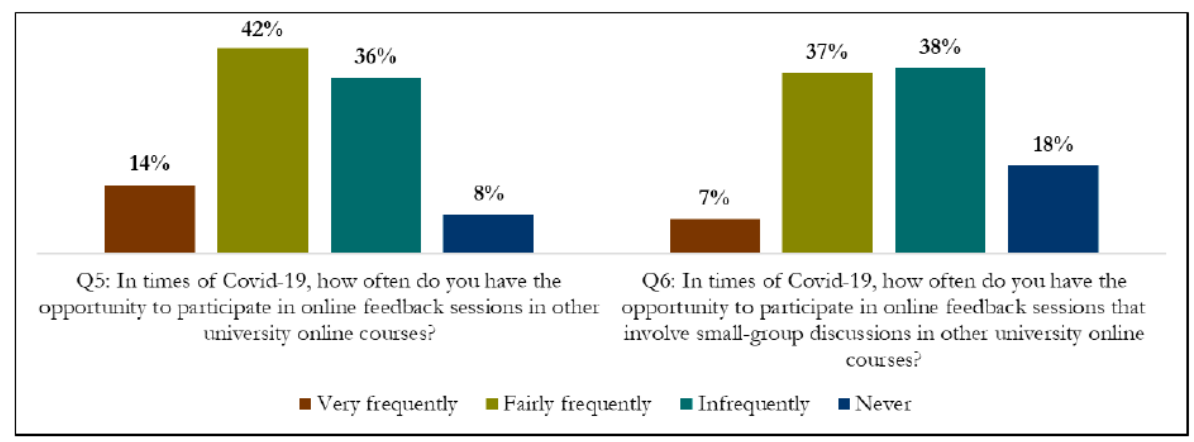

FIGURE 4

Students' responses to Questions 5 and 6 of the 11 -item survey $(\mathrm{N}=76)$.

Another key finding is that $18 \%$ of the respondents considered that the online discussions in small groups were not useful for them (Q2 in Fig. 3). Some of their comments include the following: "It was difficult to find somebody to start the discussion", "this activity requires time", "It is better to discuss with the instructor", and "I would like to have found more robust arguments from my partners". Many students (87\%) mentioned they had sufficient time for discussing with their partners (Q4 in Fig. 3), and importantly, nearly all the respondents $(96 \%)$ reported that the online feedback provided by their instructor was useful for them (Q3 in Fig. 3). Some of their reasons include: "It was useful that the instructor has provided us feedback based on the conclusions we reached in the groups", "thanks to this, I understood the reasons that supported the answer to a question", and "feedback helped me to go further the arguments discussed with my partners".

Lastly, Table 2 shows the respondents' average scores along with the standard deviations on questions from 7 to 11 (Appendix). The maximum possible average score that could be scored for each item was five. Outcomes show that the average scores varied between 4.17 and 4.47 with a mean of 4.31 which corresponds to the "agree" choice. This leads us to assert that the students had favorable opinions about the implementation of OIFA practices in the Quantitative Physiology I course. 
TABLE 2

Descriptive statistics of survey questions 7 to 11

\begin{tabular}{llll}
\hline Question & Mean & SD & $\begin{array}{l}\text { Cronbach's alpha } \\
\text { if item deleted }\end{array}$ \\
\hline 7. I liked the online feedback sessions & 4.18 & 0.84 & 0.89 \\
8. The online feedback sessions helped me become aware of my learning & 4.17 & 0.90 & 0.89 \\
process & & & \\
& 4.36 & 0.81 & 0.92 \\
9. The online feedback sessions helped me to develop deep learning & 4.47 & 0.98 & 0.89 \\
10. Online feedback sessions should continue to be promoted in the & 4.47 & & \\
$\quad \begin{array}{l}\text { Quantitative Physiology I course } \\
\text { Online feedback sessions should be promoted in other university }\end{array}$ & 4.39 & 0.96 & 0.89 \\
online courses as well & & &
\end{tabular}

\section{Discussion AND CONCLUSIONS}

Humanity is facing one of the most serious health crises in modern history. Covid-19 crisis has brought about huge disruption and uncertainty to various aspects of everyday life (Archila et al. 2021c). This is a pandemic that will be with us for a long time and its (positive and negative) effects in fields, such as education, entertainment streaming and gaming, environment, online businesses, pharmaceutical industry, tourism and hospitality, and video conferencing, are the subject of research (Colao et al. 2020; Mailizar et al. 2020; Rapanta et al. 2020; Sintema 2020; Wen et al. 2021; Witze 2020; Yamin 2020). In the case of educational practices, Zhu and Liu (2020) note, the Covid-19 pandemic "could represent a shift from traditional, teacher-centered, and lecture-based activities towards more student-centered activities including group activities, discussions, hands-on learning activities, and limited use of traditional lectures" (p. 697). The lecture format adopted by many universities around the globe has been heavily criticized for perpetuating the outmoded instructor-centered approach (Hoidn and Klemenčič 2021). Such an approach drastically limits the opportunities students find to become engaged in instructor-student and student-student argumentative interaction (Archila et al. 2018; 2020). It is very possible that in times of Covid-19, some instructors have replaced synchronous face-to-face by synchronous online lectures.

For all the reasons just mentioned in the preceding paragraph, it makes sense to assert that this study emerged as a response to the invitation by Mahmood (2021) and Sun et al. (2020) to assume the Covid-19 crisis as an opportunity to switch from passive learning (instructor-centered learning) to active learning (student-centered learning) in online learning environments. Here we provide evidence that OIFA can be used to provide students with explicit opportunities to participate in online instructorstudent argumentative interaction. This is particularly important as Jiménez-Aleixandre and Brocos (2017) invite us to assume the creation and implementation of argumentative interaction scenarios as a priority for authentic and meaningful science education. In this regard, the outcomes suggest that students effectively communicated a claim and developed arguments when they interacted argumentatively with their instructor. However, students had trouble in communicating counterclaims and counterarguments. It is not surprising because, as Namdar and Namdar (2021) explain, students tend to ignore counterclaims and counterarguments, using only arguments related to their own views. Naturally, the situation becomes more complicated because science instructors rarely include activities such as "debate, valuing different positions and getting students to anticipate in counterarguments" (Erduran et al.2020, p. 12) in their courses.

Having demonstrated that the OIFA-based pedagogical strategy provided students with explicit opportunities to participate in instructor-student argumentative interaction during online lecturing, it is worth mentioning that this type of interaction served as a platform for the discussion of (counter) claims and (counter) arguments in different measures. This is in line with the idea that a productive argumentative 
interaction is that in which students find opportunities to experience the production of multiple elements of argumentation and reflect on such production (Baker 2009). Our results further demonstrate that this production is much more likely to occur if students are given explicit opportunities to interact argumentatively with their instructor. A less evident point but perhaps one that is even more important is that instructors should be given more explicit opportunities to interact argumentatively with their students (Wieman 2017). As instructors are fundamental for the cultivation of argumentation skills, the use of instructor-student argumentative interaction activities could prove to be advantageous for students, as well as for the instructors themself.

These results contribute to the research literature in university science education. To be precise, our contribution is that here we provide research evidence in response to the increasing calls for the need to offer students a genuine educational experience beyond just lectures which are usually found in courses even before this pandemic (Wieman 2017). Additionally, the findings of this study extend those found by Archila et al. (2018) who dealt with (1) instructor's selection of assessment data (Stage 1 in Fig. 1), (2) students' make of individual decisions (Stage 2 in Fig. 1), and (3) student-student argumentative interaction (Stage 3 in Fig. 1) as pragmatic and effective stages before (4) instructor-student argumentative interaction (Stage 4 in Fig. 1) as part of face-to-face informal formative assessment practices. Clearly, this extension is related to the fact that we provide evidence from an online (not face-to-face) science course. Moreover, the findings of our study reinforce Erduran's (2020b) claim that "the pandemic context has reiterated the importance of promoting students' understanding of uncertainty in science, acquisition of critical thinking skills, as well as the ability to engage in argumentation and problem-solving" (p. 488).

Rapanta et al. (2020) remind us that "the Covid-19 pandemic has raised significant challenges for the higher education community worldwide. A particular challenge has been the urgent and unexpected request for previously face-to-face university courses to be taught online" (p. 923). With this in mind, it is plausible to suggest that although our results were obtained amidst this pandemic, they transcend it. The reason for this is that university online science courses continue and will continue to be a strategic alternative for higher education institutions in the post-pandemic era. Thus, the results lead us to conclude that OIFA can be an educational resource for online lecturing to large groups. In particular, our findings are relevant for two reasons. First, Cosi et al. (2020) and Duss (2020) insist that more attention should be given to the promotion of genuine and meaningful formative assessment practices in university education. Second, almost half of the participating students reported that they never or infrequently had the opportunity to participate in online feedback sessions in other university online courses. This is something that concerns as Mizokami (2018) associates the one-way transmission of knowledge in lecture-style classes to passive learning, and student engagement in activities such as writing and discussion to active learning. He also stresses the importance of externalizing cognitive processes in these activities. In our case, this occurred when students explicitly reflected on their argumentation process. Therefore, our outcomes add empirical evidence to the claim that argumentative interaction is a form of active learning (Archila et al. 2018; 2020, 2021a; Baker 2009; JiménezAleixandre 2007; Muller Mirza 2015).

Finally, it is reasonable to say that the online feedback sessions provided an opportunity for the participating students to interact argumentatively with their instructor; who used this interaction as a platform to give them useful feedback — the heart of formative assessment - (Cowie 2012; Duss 2020; Rached and Grangeat 2021). Thomas and Rogers (2020) maintain that due to the Covid-19 crisis "many countries in the world are now participants in the biggest unplanned experiment that education has ever seen" (p. 89). For example, this crisis has led higher education institutions to rethink the educational practices they wish to implement for their students in the post-pandemic era. Hence, the empirical study reported in this article provides a useful and original basis for the creation, implementation, and evaluation of pragmatic, effective, and realistic actions in giving students opportunities to participate in OIFA scenarios which engage them in deep active learning through argumentative interaction. 


\section{LIMITATIONS AND FURTHER RESEARCH}

We acknowledge that the present study has several important limitations. First, we only focused our analysis on instructor-student argumentative interaction. Arguably, examining student-student interaction would be crucial to have a complete understanding of the effects of the OIFA-based pedagogical strategy on opportunities to develop genuine educational practices. Second, examples of the questions selected by the instructor were not included in this article. This limited the possibility to illustrate in a deeper manner how the instructor-student argumentative interactions occurred. Third, we adopted a qualitative and dichotomous approach in the analysis of instructor-student interaction. It would be interesting to explore such interactions from a quantitative perspective, estimating the percentage of (counter) claims, (counter) arguments produced by each student, week-by-week, and determining the percentage of students who developed a desirable argumentation process. Our intention was only to provide evidence that OIFA can be used to provide undergraduates with explicit opportunities to participate in instructor-student argumentative interaction. Accordingly, here we only provide a general view of the percentage of the aspects of argumentation that were produced by the class (not by each student) in the seven feedback sessions. And fourth, the reduced number of items in our intervention feedback survey did not allow us to conduct a more rigorous validation process. Hence, caution needs to be taken regarding the generalizability of our outcomes.

Future research is needed to elucidate how to effectively adapt the OIFA-based pedagogical strategy to university online asynchronous science courses. Moreover, future studies might examine the role of studentstudent argumentative interaction in the co-construction of divergent thinking habits that allow students to students anticipate counterarguments. Furthermore, it would be important to carry out more research focusing particularly on university online science courses, online lecturing to large groups, OIFA, and argumentative interaction in other countries. This would help validate the present study's results, in turn contributing to enhancing educational practices. Most importantly, future studies should be guided by the claim that more efforts and resources should be invested in changing the traditional lecture format since "research has established that people do not develop true understanding of a complex subject such as science by listening passively to explanations" (Wieman 2017,p. 9).

\section{SUPPLEMENTARY MATERIALS}

Appendix: Survey (pdf)

\section{ACKNOWLEDGMENTS}

The authors warmly thank the students at the Quantitative Physiology I course for their participation in this empirical study. This project was funded by the Vice-Presidency of Research and Creation, Universidad de los Andes, Bogotá, Colombia.

\section{References}

Archila, P. A. (2015). Using history and philosophy of science to promote students' argumentation. A teachinglearning sequence based on the discovery of oxygen. Science \& Education, 24(9), 1201-1226.

Archila, P. A. (2017). Using drama to promote argumentation in science education: The case of "Should've". Science ఓEducation, 26(3-4), 345-375. 
Archila, P. A. (2018). Evaluating arguments from a play about ethics in science: A study with medical learners. Argumentation, 32(1), 53-76.

Archila, P. A., Molina, J., \& Truscott de Mejía, A.-M. (2018). Using formative assessment to promote argumentation in a university bilingual science course. International Journal of Science Education, 40(13), 1669-1695.

Archila, P. A., Molina, J., \& Truscott de Mejía, A.-M. (2019). Promoting undergraduates' awareness of the importance of thinking critically about false or inaccurate scientific information presented in news articles. Revista Eureka sobre Enseñanza y Divulgación de las Ciencias, 16(13), 3106.

Archila, P. A., Molina, J., \& Truscott de Mejía, A.-M. (2020). Using historical scientific controversies to promote undergraduates' argumentation. Science \& Education, 29(3), 647-671.

Archila, P. A., Molina, J., Danies, G., Truscott de Mejía, A.-M., \& Restrepo, S. (2021a). Providing undergraduates with opportunities to explicitly reflect on how news articles promote the public (mis)understanding of science. Science \& Education, 30(2), 267-291.

Archila, P. A., Molina, J., \& Truscott de Mejía, A.-M. (2021b). Fostering bilingual written scientific argumentation (BWSA) through collaborative learning (CL): evidence from a university bilingual science course. International Journal of Science Education, 43(1), 1-29.

Archila, P. A., Molina, J., \& Truscott de Mejía, A.-M. (2021c). Using a controversy about health, biology, and indigenous knowledge to promote undergraduates' awareness of the importance of respecting the traditions and beliefs of indigenous communities: The case of paragonimiasis in Colombia. Cultural Studies of Science Education, 16(1), 141-171.

Archila, P. A., Danies, G., Molina, J., Truscott de Mejía, A.-M., \& Restrepo, S. (2021d). Towards Covid-19 literacy. Science \& Education, 30(4), 785-808.

Baker, M. J. (2009). Argumentative interactions and the social construction of knowledge. In N. Muller Mirza \& A.N. Perret-Clermont (Eds.), Argumentation and education: Theoretical foundations and practices (pp. 127-144). New York: Springer.

Bonwell, C. C., \& Eison, J. A. (1991). Active learning: Creating excitement in the classroom. ASHE-ERIC HigherEducation Report No. 1. Washington: The GeorgeWashington University.

Bryman, A. (2016). Social research methods (5th ed.). Oxford: Oxford University Press.

Cohen, J. (1960). A coefficient of agreement for nominal scales. Educational and Psychological Measurement, 20(1), $37-46$.

Colao, A., Piscitelli, P., Pulimeno, M., Colazzo, S., Miani, A., \& Giannini, S. (2020). Rethinking the role of the school after COVID-19. The Lancet Public Health, 5(7), 370.

Cosi, S., Voltas, N., Lázaro-Cantabrana, J. L., Morales, P., Calvo, M., Molina, S., \& Quiroga, M. Á. (2020). Formative assessment at university using digital technology tools. Profesorado, Revista de Curriculum y Formación del Profesorado, 24(1), 164-183.

Cowie, B. (2012). Focusing on the classroom: Assessment for learning. In B. J. Fraser, K. G. Tobin, \& C. J. McRobbie (Eds.), Second international handbook of science education (pp. 679-690). Dordrecht: Springer.

Duss, K. (2020). Formative assessment and feedback tool. Basel: Springer.

Erduran, S. (2020a). Science education in the era of a pandemic. Science \& Education, 29(2), 233-235.

Erduran, S. (2020b). Bringing nuance to "the science" in public policy and science understanding. Science \& Education, 29(3), 487-489.

Erduran, S. (2021). Science education and the pandemic, 1 year on. Science \& Education, 30(2), 201-204.

Erduran, S., \& Jiménez-Aleixandre, M. P. (2007). Argumentation in science education: An overview. In S. Erduran \& M. P. Jiménez-Aleixandre (Eds.), Argumentation in science education: Perspectives from classroom-based research (pp. 3-27). New York: Springer.

Erduran, S., Guilfoyle, L., \& Park, W. (2020). Science and religious education teachers' views of argumentation and its teaching. Research in Science Education, https://doi.org/10.1007/s11165-018-9758-z

Fleiss, J. L. (1971). Measuring nominal scale agreement among many raters. Psychological Bulletin, 76(5), 378-382. 
George, D., \& Mallery, P. (2020). IBM SPSS Statistics 26 Step by Step (16th ed.). New York: Routledge.

Gogus, A. (2012). Active learning. In N. M. Seel (Ed.), Encyclopedia of the sciences of learning (pp. 77-80). Springer: New York.

Hoidn, S., \& Klemenčič, M. (2021). Introduction and overview. In S. Hoidn \& M. Klemenčič (Eds.), The Routledge international handbook of student-centered learning and teaching in higher education (pp. 1-13). Abingdon: Routledge.

Holmeier, M., Grob, R., Nielsen, J. A., Rönnebeck, S., \& Ropohl, M. (2018). Written teacher feedback: Aspects of quality, benefits and challenges. In J. Dolin \& R. Evans (Eds.), Transforming Assessment (175-208). Cham: Springer.

Jiménez-Aleixandre, M. P. (2007). Designing argumentation learning environments. In S. Erduran \& M. P. JiménezAleixandre (Eds.), Argumentation in science education: Perspectives from classroom-based research (pp. 91-115). New York: Springer.

Jiménez-Aleixandre, M. P., \& Brocos, P. (2017). Processes of negotiation in socio-scientific argumentation about vegetarianism in teacher education. In F. Arcidiacono, \& A. Bova (Eds.), Interpersonal argumentation in educational and professional contexts (pp. 117-139). Cham: Springer.

Jiménez-Aleixandre, M. P., \& Brocos, P. (2021). Argumentation and inquiry learning. In R. G. Duncan, \& C. A. Chinn (Eds.), International handbook of inquiry and learning (pp. 221-238). New York: Routledge.

Jiménez-Aleixandre, M. P., \& Puig, B. (2012). Argumentation, evidence evaluation and critical thinking. In B.J. Fraser, K. G. Tobin, \& C. J. McRobbie (Eds.), Second international handbook of science education (pp. 1001-1015). Dordrecht: Springer.

Mailizar., Almanthari, A., Maulina, S., \& Bruce, S. (2020). Secondary school mathematics teachers' views on elearning implementation barriers during the COVID-19 pandemic: The case of Indonesia. Eurasia Journal of Mathematics, Science and Technology Education, 16(7), 1-9.

Mahmood, S. (2021). Instructional strategies for online teaching in COVID-19 pandemic. Human Behavior and Emerging Technologies, 3(1), 199-203.

Matsushita, K. (2018). An invitation to deep active learning. In K. Matsushita (Ed.), Deep active learning (pp. 1533). Springer: Singapore.

Mayer, R. (2004). Should there be a three-strikes rule against pure discovery learning? The case for guided methods of instruction. The American Psychologist, 59(1), 14-19.

Mindrila, D. (2017). Exploratory factor analysis: An overview. In D. Mindrila (Ed.), Exploratory factor analysis (pp. 1-25). Nova Science Publishers: New York.

Ministerio de Educación Nacional. (2008). La revolución educativa: Plan sectorial de educación 20062010. Available at: https://www.mineducacion.gov.co/1621/articles-156179_recurso_7.unknown\#: :text=Los\%20rangos\%2 0de\%20edad\%20utilizados,Superior\%20(17\%20a\%2021)

Mizokami, S. (2018). Deep active learning from the perspective of active learning theory. In K. Matsushita (Ed.), Deep active learning (pp. 79-91). Springer: Singapore.

Morton, A. (2009). Lecturing to large groups. In H. Fry, S. Ketteridge \& S. Marshall (Eds.), A handbook for teaching and learning in higher education (pp. 58-71). New York: Routledge.

Muller Mirza, N. (2015). Can we learn through disagreements? A sociocultural perspective on argumentative interactions in a pedagogical setting in higher education. Teaching Innovations, 28(3), 145-166.

Namdar, A. O., \& Namdar, B. (2021). Blending creative drama and computer-supported collaborative learning for socioscientific argumentation. In W. A. Powell (Ed.), Socioscientific issues-based instruction for scientific literacy development (pp. 132-160). Hershey: IGI Global.

Rached, E., \& Grangeat, M. (2021). French teachers' informal formative assessment in the context of inquiry-based learning. International Journal of Science Education, 43(3), 385-406. 
Rapanta, C., Botturi, L., Goodyear, P., Guàrdia, L., \& Koole, M. (2020). Online university teaching during and after the Covid-19 crisis: Refocusing teacher presence and learning activity. Postdigital Science and Education, 2(3), 923-945.

Ruiz-Primo, M. A. (2015). Cognitive labs. In R. Gunstone (Ed.), Encyclopedia of science education (pp. 167-171). Dordrecht: Springer.

Rush, S. C. (2019). Implementing a qualitative video and audio analysis study using the Transana platform: Applications for research in education settings. SAGE Research Methods Cases. https://doi.org/10.4135/9781 526484437

Salmon, G. (2013). E-tivities: The key to active online learning (2nd ed.). New York: Routledge.

Sintema, E. J. (2020). Effect of COVID-19 on the performance of grade 12 students: Implications for STEM education. Eurasia Journal of Mathematics, Science and Technology Education, 16(7), 1-6.

Sun, L., Tang, Y., \& Zuo, W. (2020). Coronavirus pushes education online. Nature Materials, 19(6), 687.

Sunal, C. S., \& Wright, V. H. (2012). Online learning. In N. M. Seel (Ed.), Encyclopedia of the sciences oflearning (pp. 2499-2502). Springer: New York.

Thomas, M. S. C., \& Rogers, V. (2020). Education, the science of learning, and the COVID\#19 crisis. Prospects, 49(1-2), 87-90.

Viera, A. J. \& Garrett, J. M. (2005). Understanding interobserver agreement: The Kappa statistic. Family Medicine, $37(5), 360-363$.

Wen, J., Wang, W., Kozak, M., Liu, X., \& Hou, H. (2021). Many brains are better than one: The importance of interdisciplinary studies on COVID-19 in and beyond tourism. Tourism Recreation Research, 46(2), 310-313.

Wieman, C. (2017). Improving how universities teach science. Cambridge: Harvard University Press.

Witze, A. (2020). Universities will never be the same after the coronavirus crisis. Nature, 582(7811), 162-164.

World Health Organization (2020a). Coronavirus disease 2019 (COVID-19) Situation Report - 52. Geneva: World Health Organization. March 12, https://www.who.int/docs/default-source/coronaviruse/situation-reports/2 0200312-sitrep-52-covid-19.pdf?sfvrsn=e2bfc9c0_4. Accessed 11 March 2021.

World Health Organization (2020b). Novel Coronavirus(2019-nCoV) Situation Report - 11. Geneva: World Health Organization. January 31, https://www.who.int/docs/default-source/coronaviruse/situation-reports/2020013 1-sitrep-11-ncov.pdf?sfvrsn=de7c0f7_4. Accessed 11 March 2021.

Yamin, M. (2020). Counting the cost of COVID-19. International Journal of Information Technology, 12(2), 311317.

Yin, Y., Tomita, M. K., \& Shavelson, R. J. (2014). Using formal embedded formative assessments aligned with a shortterm learning progression to promote conceptual change and achievement in science. International Journal of Science Education, 36(4), 531-552.

Zhu, X., \& Liu, J. (2020). Education in and after Covid-19: Immediate responses and long-term visions. Postdigital Science and Education, 2(3), 695-699.

\section{AdDitionAL INFORMATION}

How to cite this article: Archila P. A., Restrepo S., Truscott de Mejia A. M., Rueda-Esteban R. y Bloch N. I. (2022) Fostering instructor-student argumentative interaction in online lecturing to large groups: a study amidst the Covid-19 pandemic. Revista Eureka sobre Enseñanza y Divulgación de las Ciencias 19(1), 1101. doi: 10.25267/Rev_Eureka_ensen_divulg_cienc.2022.v19.i1.1101 